\title{
MODEL DAN DAMPAK MOBILISASI POLITIK PEMILIHAN KEPALA DESA (Studi Kasus: Desa Bontomatinggi Kabupaten Maros Sulawesi Selatan Tahun 2016) \\ Oleh: \\ La Ode Muhammad Elwan ${ }^{1}$

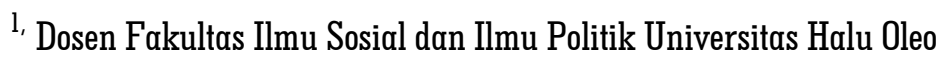 muh.elwan@uho.ac.id
}

\begin{abstract}
The purpose of this study was to determine the impact of village head elections after the implementation of the Bontomatinggi Village Head election in Maros Regency in 2016.

The research method used is a qualitative research method with a descriptive approach to analysis and using the theory of political mobilization, data collection using interview, observation and documentation techniques. The data analysis technique used by the author is a qualitative data analysis technique that is by searching and compiling systematically from the results of interviews, observations and documentation and then selecting the data needed and making conclusions that are easy to understand.

Based on the results of the study, direct and indirect mobilization models and the impacts that occurred in the community after the election of Maros Regency Bontomatinggi Village Chief occurred several models such as socialization of village head candidates, mass mobilization, open campaign (direct mobilization model) and dialogical campaigns conducted from home to home (direct mobilization model). The impact of the model and after the election is that there is an unnatural mobilization model such as intimidation and threats to voters, giving facilities and money politics, black campaigns and spreading slander. Some of the factors that influence the voters' decision to elect a village head are the lack of education level of the community, mobilized communities are afraid that there will be violence and utterances of hatred from the candidates and the successful team if they do not follow their wishes.
\end{abstract}

\section{Keywords : Political Mobilization Model, the impact of village head elections}

\section{PENDAHULUAN}

Berlakunya Peraturan Pemerintah Republik Indonesia Nomor 72 Tahun 2005 tentang Desa telah menciptakan sistem baru dalam proses pilkades dan tidak dapat dipungkiri bahwa keterlibatan masyarakat dalam pemilihan kepala desa ini telah meningkatkan intensitas peran masyarakat pedesaan dalam mengembangkan kehidupan berdemokrasi.

Pemilihan kepala desa (Pilkades) merupakan praktek demokrasi langsung di pedesaan. Dalam praktek demokrasi langsung seperti ini yang terpenting dikedepankan adalah proses pemilihan yang memegang teguh tiga aspek penting, yaitu aspek kompetisi antar calon, partisipasi dan kebebasan. Aspek kompetisi berkaitan dengan orang-orang yang mencalonkan diri sebagai kepala desa dan cara-cara yang dipakai untuk menjadikan mereka ini sebagai calon kepala desa.

Aspek partisipasi berkaitan dengan pemahaman masyarakat terhadap pemilihan kepala desa, yaitu cara mereka merumuskan tipe kepemimpinan kepala desa dan model mereka membangun kesepakatan politik dengan para 
calon kepala desa. Aspek kebebasan erat kaitannya dengan suasana warga pemilih dalam menentukan pilihan politiknya kepada para calon kepala desa.

Berdasarkan pertimbangan tiga aspek penting dalam proses pemilihan kepala desa tersebut, diharapkan akan terselenggara praktek demokrasi langsung melalui lembaga penyelenggara, proses dan produk pemilihan yang baik serta bermanfaat nyata bagi masyarakat desa. Sehingga bisa dikatakan bahwa pemilihan kepala desa akan sukses, jika tiga aspek penting dalam proses pemilihan tersebut diperhatikan secara cermat.

Salah satu instrumen demokrasi desa telah hadir di masyarakat desa sejak sebelum era Indonesia, yakni pemilihan lurah, atau sekarang dikenal dengan pemilihan kepala desa (Pilkades). Masyarakat desa mengenal Pilkades ketika Thomas Stanford Raffles, gubernur jendral Indonesia 1811-1816, mengeluarkan regulasi yang merubah sistem politik masyarakat desa. Kepala desa (saat itu dikenal sebagai lurah), yang sebelumnya diangkat oleh pemerintah di atasnya, diubah menjadi dipilih oleh masyarakat desa. Tujuan penerapan regulasi tersebut adalah untuk merubah budaya lurah yang cenderung terikat pada penguasa pribumi, serta memperkenalkan model demokrasi barat (Nurkholis, 2011). Penerapan regulasi tersebut dinilai tepat, dengan dipilihnya lurah oleh warga desa, maka pengaruh raja mengalami penurunan. Model demokrasi barat tersebut merubah pola hubungan lurah. Sebelumnya, jabatan lurah bersifat transaksional antara calon lurah dengan raja. Setelah regulasi diterapkan, pola hubungan berubah menjadi hubungan antara calon lurah dengan warga desa.

Masyarakat desa adalah komunitas politik paling bawah yang ada di indonesia dan mudah dimobilisasi terutama masyarakat hal itu ditunjukan dengan terdapatnya pemerintahan paling bawah dari hirarkhi pemerintahan di Indonesia. Selain memiliki pemerintahan desa, masyarakat desa juga memiliki budaya demokrasi untuk terlibat dalam penyelenggaraan pemerintahan, khususnya dalam menentukan kepala pemerintahan desa

Demokrasi desa dalam bentuk pemilihan kepala pemerintahan desa terus diterapkan hingga masa Indonesia, melalui rezim orde lama, orde baru, hingga saat ini. Perjalanan panjang demokrasi tersebut juga menempatkan pemilihan kepala desa sebagai pemilu dengan karakteristik yang berbeda dibanding pemilu lain. Perbedaan itu terwujud pada pelaksanaan Pilkades yang memiliki format berbeda dengan pemilu-pemilu lain. Pilkades tidak melibatkan partai secara formal, berbeda dengan Pilkada Pilgub ataupun Pilpres yang mensyaratkan dukungan partai. Bisa saja secara informal partai menyediakan mesin partai untuk mendukung salah satu calon, namun itu tidak lazim di Pilkades. Apalagi partai tidak memiliki mesin mobilisasi yang dapat diandalkan (Tawakkal, 2009). Terlepas dari lemahnya mesin partai, konsekuensi dari perbedaan format tersebut adalah, calon kepala desa tidak memiliki mesin politik yang siap digunakan untuk memobilisasi pemilih.

Calon kepala desa dihadapkan pada kenyataan harus membangun sendiri mesin politiknya. Calon kepala desa harus bisa memanfaatkan unsur-unsur yang ada di masyarakat desa untuk membangun mesin politik yang kuat, yang mampu melakukan mobilisasi pemilih. Tidak jarang juga para calon kepala desa yang akan bertarung memanfaatkan tokoh-tokoh masyarakat seperti imam desa, dusun bahkan orang-orang yang mempunyai modal, mereka di jadikan sebagai tim sukses para calon karena di anggap sebagai orang yang berpengaruh dalam mengarahkan atau mendorong masyarakat untuk ikut berpartisipasi dalam pemilihan kepala desa.

Mobilisasi politik suatu aktifitas atau kegiatan politik yang bukan berdasarkan keinginan sendiri tetapi atas dorongan dan ajakan dari pihak lain dalam arti dikerahkan secara sengaja. Misalnya kegiatan aksi pembatalan hasil Pilkada atau memaksa masyarakat untuk mendukung calonnya yang dikoordinir oleh team sukses dari kandidat, massa melakukannya tidak atas inisiatif sendiri. Mobilisasi yang dilakukan untuk mencari dukungan 
Vol.1 No.4. Januari 2019. pp.1-17. Copyright@2019 PUBLICUHO Faculty of Social and Political Sciences Halu Oleo University, Kendari, Southeast Sulawesi, Indonesia. ISSN: 2460-058X | e-ISSN: 2621-1351. Open Access at: http://ojs.uho.ac.id/index.php/PUBLICUHO

CC Jounal publiuho is licensed under a Creative Commons Attribution 4.0 International License, which permits
unrestricted use, distribution, and reproduction in any medium, provided the original work is properly cited.

tentunya tidak hanya dilakukan oleh orang-orang yang berpengaruh saja namun ada juga yang sebagian besar memaksa anggota keluarganya untuk memilih calon yang dia dukung sehingga menimbulkan konflik dalam rumah tangga, dimana mereka mengajak keluarga atau masyarakat untuk memilih pasangan calon yang mereka unggulkan dan mereka tidak segan-segan memberikan bantuan tersebut kepada masyarakat.

Dalam setiap pelaksanaan pemilihan kepala desa (kades), suasana politik di wilayah desa seringkali memanas. Hal itu tak lepas adanya persaingan antar kubu yang menginginkan tampuk kekuasaan di desa. Bahkan sering terdengar setiap pelaksanaan pemilihan kades, mobilisasi pemilih menjadi hal yang sering terlihat, hal ini perlu diwaspadai mengingat pemilhan kepala desa yang baik, jujur serta sportif adalah awal dari demokratisnya sebuah negara agar berdampak positif pada pemilihan-pemilihan yang lebih besar seperti pemilihan bupati, walikota, gubernur bahkan presiden tetapi faktanya pemilhan kades selalu berujung dengan kekecewaan yang di rasakan oleh masyarakat, calon atau tim sukses yang tidak ingin hal itu terjadi di karenakan tidak adanya persaingan secara sehat pada saat pemilihan, bukannya visi dan misi yang menjadi pertimbangan masyarakat dalam memilih calon tetapi mereka seolah-olah dipengaruhi oleh para kelompok yang ingin memegang kekuasaan.

Pemilihan kepala desa di Desa Bontomatinggi Kecamatan Tompobulu Kabupaten Maros tahun 2016 lalu telah dilaksanakan, dimana ada 3 calon yang bertarung di antaranya Haerul, Abdullah S.E dan Muliati. Namun pemilihan tersebut di nodai dengan adanya mobilisasi yang dimana tim sukses dari salah satu calon yakni Haerul dan Abdullah,S.E yang memiliki figur berpengaruh memanfaatkan kekuasaannya dalam mengarahkan masyarakat untuk memilih sedangkan Muliati sebagai calon perempuan hanya mengandalkan faktor kekerabtan dan keluarga. Mobilisasi yang dilakukan oleh tim sukses dikategorikan dalam 2 model, yakni mobilisasi langsung dan tidak langsung. Mobilisasi langsung merupakan kegiatan mobilisasi dalam bentuk pengerahan terhadap pemilih dan mobilisasi tidak langsung merupakan kegiatan mobilisasi dalam bentuk pemengaruhan cara pikir atau cara pandang pemilh dan biasanya melalui media komunikasi. Kurangnya pengetahuan dan pendidikan politik menjadi faktor utama masyarakat desa Bontomatinggi mudah di mobilisasi sehingga pemangku kepentingan atau tim sukses memanfaatkan kesempatan ini agar masyarakat ikut serta dalam pemilihan walaupun dengan cara yang salah karena adanya dorongan secara paksa dari pihak yang memiliki kepentingan.

Berdasarkan data di atas, penulis tertarik dan mencoba mengkaji bagaiman Model dan Dampak Mobilisasi Politik Pemilihan Kepala Desa" dalam pilkades desa Bontomatinggi Kabupaten Maros Tahun 2016.

\section{TINJAUAN PUSTAKA}

\section{Konsep Mobilisasi Politik}

Mobilisasi menurut Stefano (2007) dalam Fatma (2016 : 10) merupakan keanekaragamn proses keterlibatan masyarakat dalam suatu usaha rekruitmen masa dengan tujuan tertentu, dan mobilisasi secara struktural terjadi pada masa industrialisasi dan modernisasi.

Menurut Stefano (2007), Mobilisasi politik dikategorikan dalam 2 bentuk, yakni mobilisasi langsung dan mobilisasi tidak langsung. Mobilisasi langsung merupakan kegiatan mobilisasi dalam bentuk pengerahan terhadap pemilih agar melakukan tindakan politik sebagaimana yang dikehendaki. Mobilisasi politik tidak langsung merupakan kegiatan mobilisasi dalam bentuk pemengaruhan cara pikir atau cara pandang pemilih, sehingga pemilih akan mengekspresikan pemahamannya dalam bentuk keputusan politik pemilih.

Pembedaan kategori antara mobilisasi langsung dan tidak langsung berdasar pada mekanisme-mekanisme mobilisasi yang dilakukan oleh para partai atau pemangku kepentingan dalam sebuah daerah. Mobilisasi langsung dapat dilakukan dengan memberikan instruksi-instruksi melalui mekanisme kepada para pemilih 
seperti sosialisasi langsung, kampanye terbuka, menggerakkan, mengerahkan simpatisan melakukan aksi-aksi politik dan lain sebagainya.

Sedangkan mobilisasi tidak langsung dapat dilakukan melalui media seperti kampanye dialogis, seminarseminar, mempengaruhi cara pandang atau cara fikir pemilih melalui sosial media maupun iklan di media mainstream.

Mobilisasi pula di artikan sebagai usaha aktor untuk mempengaruhi distribusi kekuasaan. Mobilisasi didefinisikan sebagai pengembangan sebuah hubungan sosial (merujuk pada istilah yang digunakan Weber) sesuai dengan penjelasan pada Jeffrey A. Karp and Susan A. Banducci Part Politicis (2007 13:217) antara dua aktor, individu dan partai. Konsep aktivitas mobilisasi terdiri dari 3 proses: proses kepentingan (dimensi kognitif), proses pembentukan komunitas (dimensi affective), dan proses pemanfaatan instrumen (dimensi instrumental) mobilisasi politik.

Mobilisasi didefinisikan sebagai usaha aktor untuk mempengaruhi distribusi kekuasaan, suatu variabel directional diperkenalkan dalam rangka menggambarkan dengan tepat jenis hubungan yang berkembang antara partai dan individu. Mobilisasi politik bukan sekedar sebagai proses dimana warga negara diarahkan pada keterlibatan politik Sedangkan politik salah satu perjuangan untuk memperoleh kekuasaan atau sebagai teknik menjalankan kekuasaan-kekuasaan.

Definisi tersebut dianggap masih umum dan mungkin dilihat sebagai kelebihan ataupun kekurangan sebuah pendapat umum dari konsep-konsep di masa lalu mengenai terminology mobilisasi politik. Bagaimanapun pendefinisian secara umum ini bukan berarti bahwa konsep tersebut bisa digunakan untuk melihat konsep politik, sebagaimana yang dinyatakan oleh Verba, Scholzman dan Brady $(1995,133)$ bahwa mobilisasi memiliki banyak makna. Mobilisasi dapat diartikan sedikitnya dalam 3 gejala sosial yang berbeda Pertama, dalam aspek sosial ekonomi, sebagaimna didefinisikan dalam teori mobilisasi sosial tradisional, mobilisasi mengacu pada proses "pertimbangan sosial dan pembangunan ekonomi". Di dalam proses ini besarnya jumlah individu yang telah terurbanisasi sudah menjadi terpelajar dan telah ditunjukkan pada pembagian peran dalam ekonomi (Almond dan Powell 1966,284).

Menurut Karp dan Banducci, Mobilisasi politik merupakan sebuah cara yang besar untuk merekrut individu atau kelompok agar supaya bisa ikut berpartisipasi dalam proses politik. Mobilisasi secara sederhana selalu dilawankan dengan partisipasi, partisipasi politik adalah keterlibatan warga dalam segala tahapan kebijakan mulai dari sejak pembutan keputusan sampai dengan penilaain keputusan, termaksud juga peluang untuk ikut serta dalam pelaksanaan keputusan. Keikutsertaan warga dalam proses politik tidaklah hanya berarti warga mendukung keputusan atau kebijakan yang telah digerakkan oleh pemimpinnya, karena kalau ini terjadi maka istilah yang tepat adalah "Mobilisasi politik".

Perlu di ketahui bahwa kontrol terhadap partisipasi politik (Mobilisasi yang berlebihan) dalam pilkada hanya akan menyebabkan krisis partisipasi politik (Myron Weiner), sehingga yang terjadi adalah irasional perilaku politik masyarakat. Selain disebabkan oleh kontrol yang dilakukan oleh aparatur pemerintahan hal lain yang menyebabkan irasionalnya kran-kran pendidikan politik masyarakat adalah di tutupnya kran-kran pendidikan politik yang seharusnya di perankan secara optimal oleh Organisasi non pemerintahan serta pencedraan demokrasi melalui perilaku elit yang tidak demokratis. Perilaku elit politik yang tidak demokratis dapat berupa : pemberian suara (money politics) , Paksaan terhadap organisasi massa, keberpihakan pada salah satu pasangan calon dan memanfaatkan ghost votes, (Leo Agustino, 2009: 195-196) 
Vol.1 No.4. Januari 2019. pp.1-17. Copyright@2019 PUBLICUHO Faculty of Social and Political Sciences Halu Oleo University, Kendari, Southeast Sulawesi, Indonesia. ISSN: 2460-058X | e-ISSN: 2621-1351. Open Access at: http://ojs.uho.ac.id/index.php/PUBLICUHO

Jounal publiuho is licensed under a Creative Commons Attribution 4.0 International License, which permits unrestricted use, distribution, and reproduction in any medium, provided the original work is properly cited.

Samuel P. Huntintong (1994) menjelaskan bahwa partisipasi politik masyarkat di dasarkan atas dua kecenderungan, yaitu atas dasar kesadaran yang kemudian melahirkan partisipasi yang otonom (autonomous participastion) dan atas dasar ajakan atau di gerakkan orang lain (mobilized participation)

\section{Model Mobilisasi}

Ada 2 (dua) model dalam mobilisasi menurut (Brigitta Nedelman,1987:181-202). Pertama mobilisasi vertikal, Kedua mobilisasi horizontal, yakni menyertakan segala kemungkinan dari proses-proses internal dalam mobilisasi yang berlangsung antara partai dan individu. Model-model ini membantu untuk menganalisis keadaan politik saat ini sebagaimana ditandai oleh kesinambungan proses mobilisasi horizontal dan vertikal.

Hal ini menyisakan sebuah tugas riset mobilisasi untuk menyelidiki pernyataan yang dibuat di sini bahwa hubungan hierarkis yang dilembagakan antara partai dan individu sedang melemah sebagai sebuah hasil dari terus meningkatnya orientasi aktor ke dalam diri mereka ketika sadar akan artikulasi kepentingan, pengembangan loyalitas, dan pemanfaatan instrumen-instrumen mobilisasi.

Manifestasi lain dari politik mobilisasi adalah orientasi partai-partai politik yang lebih terfokus kepada pemilihan pejabat-pejabat dan perebutan kekuasaan atas jabatan-jabatan tertentu daripada memperkuat basis ideologi anggota partai politik. Akibatnya, koalisi-koalisi antar partai dilakukan bukan karena partai-partai yang berkoalisi memiliki kesamaan ideologi untuk membangun negara, tetapi lebih kepada peningkatan jumlah anggota partai untuk bisa menduduki jabatan-jabatan tertentu. Karena itu, jargon seperti itu "dalam politik tidak ada yang abadi kecuali kepentingan itu sendiri" menjadi dogma yang diyakini dan memang terjadi. Koalisikoalisi tersebut sangat semu dan dangkal yang dengan mudah berubah sesuai dengan "lowongan" jabatan yang ada. Politikus-politikus yang terlibat juga semakin profesional dan berubah seolah-olah menjadi politikus adalah jabatan karier dan mata pencaharian, dan bukan merupakan pejuang-pejuang prinsip atau ideologi tertentu. Akibatnya, politikus bisa dengan mudah berpindah dari satu partai ke partai lain, meski sebenarnya kedua partai tersebut memiliki ideologi yang berbeda atau bahkan berseberangan. Terkait dengan hal ini, kemampuan pengorganisasian partai menjadi salah satu aspek yang penting dalam perilaku Partai.

Proses politik dalam gaya politik mobilisasi semakin menjauhkan masyarakat ke dalam tujuan politik yang sebenarnya, yaitu demi pengaturan kehidupan bersama. Lingkaran politik menjadi lingkaran profesi yang menghidupi para politikus dalam arti yang sebenar-benarnya. Mereka hidup dari proses politik mobilisasi tanpa memiliki sumber-sumber keuangan lain di luar jabatan-jabatan politik yang disandang itu.

Akibat yang kemudian bisa diamati karena gaya politik mobilisasi adalah sikap apatis masyarakat terhadap proses pemilihan umum dan tindakan-tindakan yang terkait dengan mobilisasi massa tersebut. Tingginya angka golput menjadi parameter yang gampang diikuti. Bagi kehidupan berbangsa, karena rasa percaya diri yang berlebihan pada para pemimpin, karena merasa didukung oleh seluruh mayoritas, maka proses pengambilan keputusan bagi kebijakan sehari-hari justru semakin dijauhkan dari masyarakat konstituen. Sehingga mekanisme yang terjadi di partai menjadi tertutup dari kehidupan politis warga. Akhirnya ketika diminta untuk memilih pun sebenarnya warga tidak memiliki pengetahuan yang cukup kecuali dari pencitraan yang dimunculkan oleh media massa atau para pemangku kepentingan. Pencitraan ini hanya membuat warga memilih kucing dalam karung, karena sebenarnya tidak mengetahui apa yang dipilihnya.

Jeffrey I. (1999), Menyatakan bahwa pada sistem pemilu yang berdasar kandidat, terdapat dorongan yang lebih besar untuk melakukan mobilisasi. Caleg- caleg Partai tentu akan melakukan gerakan-gerakan politik yang bersifat independen. Masih kuatnya pengerahan mobilisasi politik, menyebabkan caleg-caleg juga melakukan mobilisasi sendiri-sendiri, yang mungkin terlepas dari mobilasi yang dilakukan partainya. Sebagaimana yang dinyatakan Liddle, agama mungkin menjadi salah satu sumber mobilisasi di Indonesia, Faktor figur, politik identitas, hingga money politik, kemungkinan juga masih menjadi sumber mobilisasi. 


\section{Struktur-Struktur Mobilisasi Gerakan}

Struktur-struktur mobilisasi gerakan sebagaimana disebut Charthy dan Mc Adam (Mc Carthy dalam Mc Adam et al 1997:145) Struktur-struktur mobilisasi gerakan ini bisa disejajarkan sebagai instrumen-instrumen mobilisasi politik yang berasal dari organisasi partai politik, seperti keluarga, jaringan kerja, serikat kerja, lembaga agama dan asosiasi sosial lain yang berafiliasi dengan partai politik.

Konsep struktur-struktur mobilisasi diambil dari terminilogi gerakan soial namun daya empiris konsep-konsep demikian berguna untuk mengungkap kasus-kasus mobilisasi politik non partai. Instrumen-instrumen sosial politik non partai sebagaimana disebut di atas, dapat digunakan partai politik dalam membangun jaringan mobilisasi politik elektoral. Struktur-struktur mobilisasi politik dapat dijadikan counter terhadap cara pandang terdahulu yang melihat mobilisasi politik bersumber dari kekuatan organisasi partai politik. Justru melalui "Struktur-struktur mobilisasi gerakan" suatu partai politik dapat membangun jaringan-jaringan serta instrumen mobilisasi politik baru secara luas. Partai politik dapat berkolaborasi dengan berbagai kekuatan sosial, ekonomi dan budaya serta memanfaatkan kekuatan-kekuatan tersebut sebagai agen mobilisasi politik baru yang akan menguntungkan partai.

Perspektif yang melokasikan partai politik sebagai instrumen utama dalam melakukan kegiatan mobilisasi politik untuk pencalonan, terlalu lemah untuk mengungkapkan adanya pengggunaan instrumen-instrumen mobilisasi politik lain di luar organisasi partai politik.

\section{Gerakan Sosial}

Gerakan sosial menurut Singh (2001: 36-37), Merupakan mobilisasi untuk menentang negara dan sistem pemerintahannya, yang tidak selalu menggunakan kekerasan dan pemberontakkan bersenjata.

Gerakan sosial dari Anthony giddens (1993) menyatakan bahwa "gerakan sosial adalah suatu upaya kolektif untuk mengejar suatu kepentingan bersama atau gerakan mencapai tujuan bersama melalui tindakan kolektif (colective action) di luar lingkup lembaga yang mapan. Jadi dapat kita tafsirkan mengenai definisi konsep gerakan sosial dari Giddens yang menyatakan bahwa gerakan sosial adalah sebuah gerakan yang dilakukan bersama-sama demi mencapai tujuan yang sama-sama diinginkan oleh kelompok atau dengan kata lain gerakan sosial adalah tindakan kolektif untuk mencapai keiinginan yang menjadi cita-cita bersama.

Sedangkan menurut Charles Tily (2004) mendefinisikan gerakan sosial sebagai rangkaian tindakan yang berkelanjutan, menunjukkan dan menyampaikan kepada masyarakat awam untuk membuat klaim bersama terhadap kelompok lainnya, menurutnya gerakan sosial merupakan kendaraan utama bagi masyarkat awam untuk berpartisipasi pada kegiatan politik publik.

Lalu definisi gerakan sosial juga muncul dari Tarrow (1998: 4-5) Mendefinisikan gerakan sosial sebagai tantangan kolektif yang dilakukan sekelompok orang yang memiliki tujuan dan solidaritas yang sama, dalam konteks interaksi berkelanjutan dengan kelompok elit, lawan, dan penguasa.

Korelasi tinjaun teoritis dan studi di atas dengan peneltian ini bahwa memberikan gambaran kepada penulis bahwa secara umum, mobisasi politik itu terjadi akibat besar kepentingan para calon atau elit di tingkat lokal, sehingga model mobilisasi politik menjadi bervariasi dan tentunya bertujuan bagaimana mempenagruhi pemilih (warga) untuk mau atau terpaksa mengikuti keinginan calon dan tim sukses yang dibentuk.

Model mobilisasi dalam pemilihan Kepala Desa, tentunnya akan berhubungan dengan bagaimana dampak yang di peroleh masyarakat setelah terlaksanannya pemilihan. 
Vol.1 No.4. Januari 2019. pp.1-17. Copyright@2019 PUBLICUHO Faculty of Social and Political Sciences Halu Oleo University, Kendari, Southeast Sulawesi, Indonesia. ISSN: 2460-058X | e-ISSN: 2621-1351. Open Access at: http://ojs.uho.ac.id/index.php/PUBLICUHO

Jounal publiuho is licensed under a Creative Commons Attribution 4.0 International License, which permits unrestricted use, distribution, and reproduction in any medium, provided the original work is properly cited.

\section{Konsep Otonomi Desa}

Widjaja (2014: 165) menyatakan bahwa otonomi desa merupakan otonomi asli, bulat, dan utuh serta bukan merupakan pemberian dari pemerintah. Sebaliknya pemerintah berkewajiban menghormati otonomi asli yang dimiliki oleh desa tersebut. Sebagai kesatuan masyarakat hukum yang mempunyai susunan asli berdasarkan hak istimewa, desa dapat melakukan perbuatan hukum baik hukum publik maupun hukum perdata, memiliki kekayaan, harta benda serta dapat dituntut dan menuntut di muka pengadilan.

Dengan dimulai dikeluarkannya Undang-Undang Nomor 23 Tahun 2014 tentang Pemerintahan Daerah memberikan landasan kuat bagi desa dalam mewujudkan "Development Community" dimana desa tidak lagi sebagai level administrasi atau bawahan daerah tetapi sebaliknya sebagai "Independent Community" yaitu desa dan masyarakatnya berhak berbicara atas kepentingan masyarakat sendiri. Desa diberi kewenangan untuk mengatur desanya secara mandiri termasuk bidang sosial, politik dan ekonomi. Dengan adanya kemandirian ini diharapkan akan dapat meningkatkan partisipasi masyarakat desa dalam pembangunan sosial dan politik. Bagi desa, otonomi yang dimiliki berbeda dengan otonomi yang dimiliki oleh daerah provinsi maupun daerah kabupaten dan daerah kota. Otonomi yang dimiliki oleh desa adalah berdasarkan asal-usul dan adat istiadatnya, bukan berdasarkan penyerahan wewenang dari Pemerintah. Desa atau nama lainnya, yang selanjutnya disebut desa adalah kesatuan masyarakat hukum yang memiliki kewenangan untuk mengatur dan mengurus kepentingan masyarakat setempat berdasarkan asal-usul dan adat-istiadat setempat yang diakui dalam sistem Pemerintahan Nasional dan berada di Daerah Kabupaten.

Landasan pemikiran yang perlu dikembangkan saat ini adalah keanekaragaman, partisipasi, otonomi asli, demokrasi, dan pemberdayaan masyarakat. Pengakuan otonomi di desa, Taliziduhu Ndraha menjelaskan sebagai berikut:

1. Otonomi desa diklasifikasikan, diakui, dipenuhi, dipercaya dan dilindungi oleh pemerintah, sehingga ketergantungan masyarakat desa kepada "kemurahan hati" pemerintah dapat semakin berkurang.

2. Posisi dan peran pemerintahan desa dipulihkan, dikembalikan seperti sediakala atau dikembangkan sehingga mampu mengantisipasi masa depan.

Otonomi desa merupakan hak, wewenang dan kewajiban untuk mengatur dan mengurus sendiri urusan pemerintahan dan kepentingan masyarakat berdasarkan hak asal-usul dan nilai-nilai sosial budaya yang ada pada masyarakat untuk tumbuh dan berkembang mengikuti perkembangan desa tersebut. Urusan pemerintahan berdasarkan asal-usul desa, urusan yang menjadi wewenang pemerintahan Kabupaten atau Kota diserahkan pengaturannya kepada desa.

\section{Kerangka Pikir}

Berdasarkan kajian pustaka, maka penulis mengembangkan Kerangka pikir untuk mempermudah proses penelitian karena mencakup tujuan dari penelitian itu sendiri. Tujuan dari penelitian ini adalah untuk mengetahui model dan dampak mobilisasi politik serta proses mobilisasi politik yang dilakukan oleh para pemangku kepentingan.

Menurut Stefano, B. (2007), Mobilisasi dikategorikan dalam 2 bentuk, yakni mobilisasi langsung dan mobilisasi tidak langsung.

Pembedaan kategori antara mobilisasi langsung dan tidak langsung berdasar pada mekanisme-mekanisme mobilisasi yang dilakukan oleh para partai atau pemangku kepentingan dalam sebuah daerah. Mobilisasi langsung dapat dilakukan dengan memberikan instruksi-instruksi melalui mekanisme kepada para pemilih seperti sosialisasi langsung, kampanye terbuka, menggerakkan, mengerahkan simpatisan, melakukan aksi-aksi politik dan lain sebagainya. Sedangkan mobilisasi tidak langsung dapat dilakukan melalui media seperti 
kampanye dialogis, seminar-seminar, mempengaruhi cara pandang atau cara fikir pemilih melalui sosial media maupun iklan di media mainstream.

Bentuk mobilisasi di atas secara garis besar bisa dikatakan kurang baik untuk perkembangan demokrasi kita, dimana dengan adanya mobilisasi dari pihak-pihak penguasa, akan berdampak terhadap masyarakat dalam partisipasi politik, merkea memilih bukan lagi dari hati nurani tetapi memilih karena faktor dorongan apa lagi sampai adanya kekerasan agar masyarakat dapat memilih calon yang di usung.

Dari beberapa bentuk mobilisasi menurut Stefano, terdapat temuan baru yang terjadi dilapangan seperti adanya bentuk mobilisasi dengan cara mengintimidasi, ancaman kepada pemilih dan kampanye hitam, inilah yang menarik dalam penelitian mengenai mobilisasi politik. Kemudian dari mobilisasi tersebut timbullah berbagai dampak negatif setelah pemilihan yang berakibat adanya ujaran kebencian.

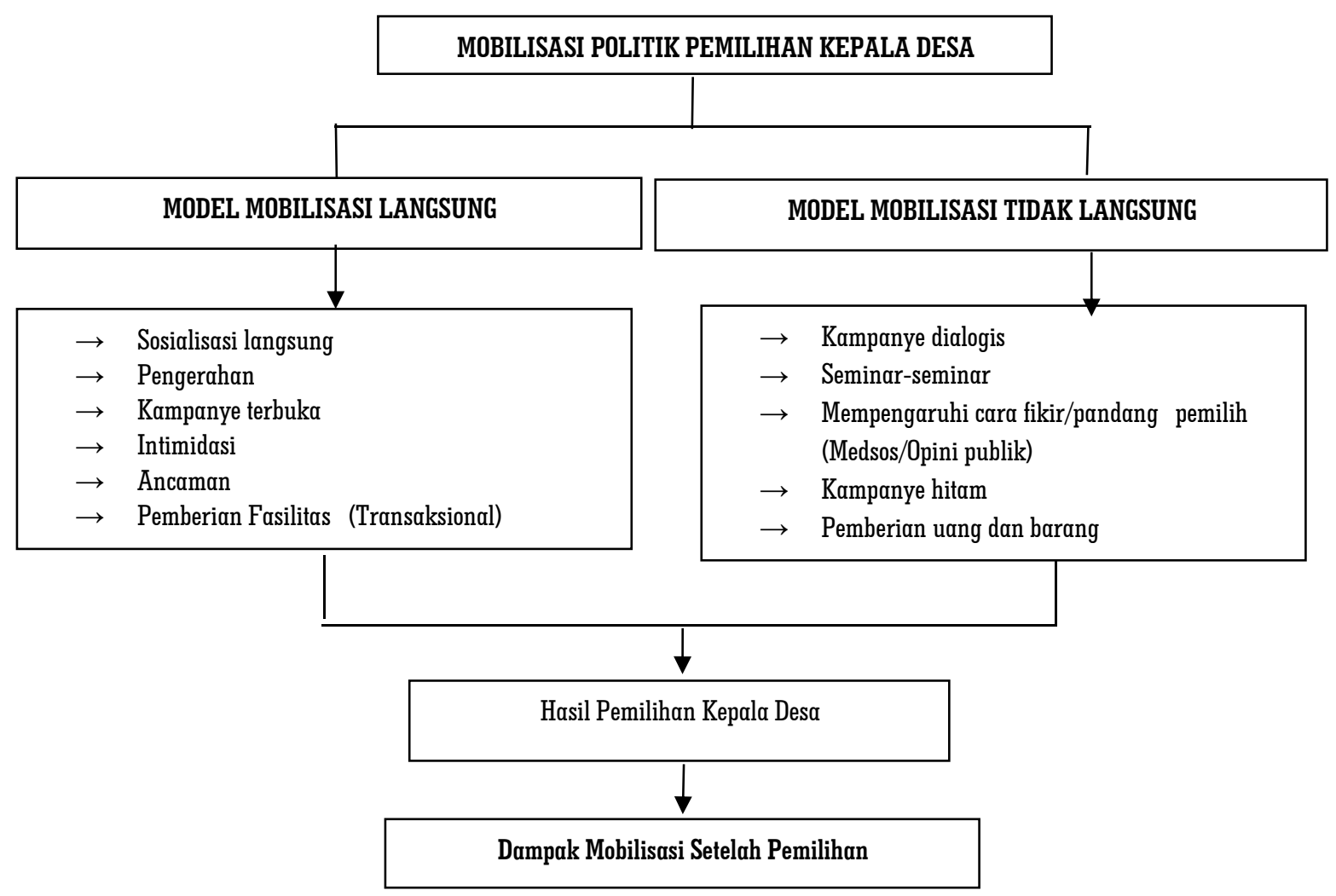

(Direduksi Menurut Stefano, 2007)

Gambar 1. Kerangka Pikir

Berdasarkan gambar diatas dapat di jelaskan bahwa Mobilisasi Politik Pemilihan Kepala Desa Bontomatinggi Kecamatan Tompobulu Kabupaten Maros Tahun 2016 dengan menggunakan konsep dari Stefano 2007, mobilisasi politik dibagi menjadi 2 bentuk yaitu mobilisasi langsung dan tidak langsung kemudian kerangka fikir di atas dikembangkan lagi oleh penulis sesuai dengan hasil dilapangan. 


\section{METODE PENELITIAN}

Berdasarkan permasalahan yang diteliti, maka jenis penelitian yang dipergunakan adalah penelitian kualitatif. Penelitian kualitatif merupakan penelitian yang berhubungan dengan ide, persepsi, pendapat, kepercayaan orang yang akan diteliti dan itu semua tidak dapat diukur dengan angka. Data yang di hasilkan dalam penelitian ini adalah data deskriptif berupa kata-kata tertulis atau lisan dari orang-orang yang betul-betul memahami permasalahan ini. Penelitian ini menggunakan pendekatan deskriptif analisis yang ingin mendapat gambaran secara utuh mengenai mobilisasi politik pemilihan kepala desa. Penelitian ini di lakukan di Desa Bontomatinggi Kabupaten Maros Sulawesi Selatan.

\section{Informan Penelitian}

Adapun informan yang dimaksud dalam penelitian ini berjumlah 11 orang, yaitu : Kepala Desa Bontomatinggi Terpilih dan calon yang kalah (3 orang), Panitia pemilihan Kepala Desa (l orang), Tim sukses /pemangku kepentingan (2 orang) dan masyarakat (5 orang). Alasan peneliti memilih informan pada penelitian ini adalah karena peneliti menganggap bahwa informan yang dipilih dapat memberikan data atau informasi yang akurat terkait permasalahan penelitian dan peneliti mengambil informan lebih banyak kepada masyarakat sebagai aktor utama yang dimobilisasi.

\section{Jenis dan Sumber data}

Terdapat 2 jenis data yang akan digunakan dalam penelitian ini. Data primer, yaitu sejumlah data yang ata keterngan yang secara langsung diperoleh melalui penelitian di lapangan dalam bentuk wawancara, meliputi keterangan dari orang-orang yang diteliti yang berhubungan dengan obyek penelitian. Data sekunder adalah data-data yang didapat dari sumber seperti foto-foto dan dokumen-dokumen lainnya yang terkait dalam penelitian ini serta melalui media lain yang bersumber dari literatur seperti arsip, notulen dan rapat.

Sumber data dalam penelitian kualitatif ini yaitu orang-orang yang diwawancarai berisi kata-kata dan tindakan yang diperoleh peneliti bersumber pada hasil wawancara dengan beberapa warga sebagai informasn selebihnya adalah seperti dokumentasi dan lain-lain. Dimana sumber data ini sangat diperlukan untuk memperoleh data dan informasi yang valid, akurat serta meyakinkan yang berkaitan dengan mobilisasi politik di desa Bontomatinggi. Untuk melengkapi sumber penelitian ini yaitu penggunaan foto dan rekaman sebagai sumber data di lapangan pada saat proses penelitian berlangsung dan dapat menjadi tanda bukti bahwa seseorang telah melakukan penelitian.

\section{Teknik Analisis Data}

Analisis data adalah proses mencari dan menyusun secara sistematis data hasil wawancara ,observasi dan dokumentasi dengan cara mengorganisasikan data dan memilih mana yang penting serta mana yang perlu dipelajari serta membuat kesimpulan sehingga mudah dipahami (Sugiyono, 2007: 333-345). Teknik analisis data yang digunakan dalam penelitian ini adalah analisis kualitatif yang digunakan peneliti sebagaimana yang dikemukakan Miles dan Hobberman. (Sugiyono,2007). Mengemukakan bahwa aktivitas dalam anaalisis data kualitatif dilakukan secara interaktif dan berlangsung secara terus menerus sampai tuntas, sehingga datanya sudah jenuh. 


\section{PEMBAHASAN}

Pada tahun 2016 pemilihan kepala desa Bontomatinggi kembali dilaksanakan, 3 calon yang maju sebagai calon masing-masing yaitu Muliati, Khaerul dan Abdullah, disinilah puncak memanasnya sebuah pemilihan kepala desa karena salah satu dari calon yaitu Muliati adalah seorang yang tinggal diluar desa Bontomatinggi dan pernah menjabat sebagai kepala desa Bontomatinggi dalam kurung waktu 2008-2014 dan suami dari Ibu Muliati tersebut juga pernah menjabat sebagai kepala Desa Bontomatinggi pada tahun 1999-2008 tetapi sebagian masyarakat tidak menginginkan jika Ibu Muliati kembali terpilih dengan berbagai alasan salah satunya bukan orang asli Desa Bontomatinggi dan ada juga masyarakat yang tidak ingin jika Kepala desanya adalah seorang perempuan, terjadilah polemik pada saat itu yang ingin memenangkan antara Khaerul atau Abdullah. Adapun Kepala Desa yang pernah memimpin Desa Bontomatinggi hingga saat ini sebagai berikut :

Tabel 1. Profil Kepala Desa Yang Pernah Memimpin di Desa Bontomatinggi Berturut-Turut Sampai Sekarang

\begin{tabular}{|c|l|c|c|c|}
\hline No & \multicolumn{1}{|c|}{ Nama } & Jabatan & Periode & Keterangan \\
\hline 1 & Muh.Hatta,Sm.Hk & Kades & $1999-2008$ & 2 Periode \\
\hline 2 & Muliaty.A & Kades & $2008-2014$ & 1 Periode \\
\hline 3 & Saharuddin,A.Ma & Plt. Kades & $2014-2016$ & Plt.Kades \\
\hline 4 & H.Sahureng,S.sos,M.Si & Plt.Kades & 2016 & Plt.Kades (6 Bulan) \\
\hline 5 & Khaerul & Kades & $2016-2022$ & Definitif \\
\hline
\end{tabular}

Sumber: Dokumen RPJMDES 2016

Berdasarkan dari tabel di atas dapat kita lihat bahwa pemilihan kepala desa Bontomatinggi sudah dilaksanakan sebanyak 3 kali namun pada tahun 2014-2016 Desa Bontomatinggi hanya dijabat oleh Pelaksana Tugas sementara sampai dilaksankannya pemilihan kepala Desa, pada akhir tahun 2016 barulah dilaksanakan pemilihan.

Hasil pemilihan kepala Desa Bontomatinggi menunjukkan terpilihnya Khaerul sebagai kepala Desa yang kelihatannya sebagian masyarakat senang dan sebagian masyarakat juga belum bisa menerima secara lapang dada karena banyak persoalan yang terjadi sampai hari $\mathrm{H}$ pemilihan. Dari jumlah perolehan suara pemilihan kepala desa Bontomatinggi tak sedikit juga yang memilih untuk golput bisa kita lihat dari tabel berikut :

Tabel 2. Perolehan Suara Pilkades Bontomatinggi Tahun 2016

\begin{tabular}{|l|l|c|c|c|c|}
\hline No & \multicolumn{1}{|c|}{ Nama } & Suara Sah & Suara Tidak Sah & Golput & DPT \\
\hline 1 & Muliaty & 236 & & & \\
\hline 2 & Khaerul & 266 & & & \\
\hline 3 & Abdullah & 235 & 1 & 221 & 959 \\
\cline { 1 - 2 } & Jumlah & 737 & & & \\
\hline
\end{tabular}

Sumber : KPPS Desa Bontomatinggi 2016

Berdasarkan dari jumlah hasil perolehan suara diatas dapat kita lihat bahwa Khaerul sebagai kepala desa terpilih meraih suara 266 di ikuti oleh Mulyati 236 suara dan Abdullah SE 235 suara. Sementara yang golput 221 orang dengan berbagai alasan di antaranya masih berada diluar kota yang memang tidak terlibat dalam mobilisasi dan pihak dari calon hanya melakukan mobilisasi dalam lingkup internal saja. Dari banyaknya yang 
Vol.1 No.4. Januari 2019. pp.1-17. Copyright@2019 PUBLICUHO Faculty of Social and Political Sciences Halu Oleo University, Kendari, Southeast Sulawesi, Indonesia. ISSN: 2460-058X | e-ISSN: 2621-1351. Open Access at: http://ojs.uho.ac.id/index.php/PUBLICUHO

Jounal publiuho is licensed under a Creative Commons Attribution 4.0 International License, which permits unrestricted use, distribution, and reproduction in any medium, provided the original work is properly cited.

memilih golput ternyata sebagian besar tidak sempat pulang untuk memilih karena mereka kerja diluar kota yang tidak memungkinkan untuk ikut berpartisipasi dalam pemilihan kepala desa selain itu tingkat pendidikan warga yang rendah dimana sebagian besar hanya tamatan SD yang berakibat belum memahami substansi demokrasi atau pendidikan politiknya masih rendah, inilah juga yang menjadi faktor mengapa masyarakat desa Bontoatinggi muda dimobilisasi sehingga masih saja terjadi ada warga atau pemilih yang menerima uang, barang dan dijanjikan jabatan, kondisi ini sesuai dengan tingkat pendidikan warga.

\section{Model Mobilisasi Politik Pemilihan Kepala Desa Bontomatinggi}

Mobilisasi merupakan dorongan yang dilakukan oleh para pemburu kekuasaan, Dimana Mobilisasi yang terjadi saat ini tidak lagi mencerminkan hal yang patut dicontoh karena dapat menghilangkan partisipasi masyarakat secara murni dalam memilih calon pemimpin, baik pemilihan kepala daerah maupun pemilihan kepala desa. Jarang terdengar mobilisasi politik yang terjadi pada pemilihan kepala desa, namun di Desa Bontomatinggi Kabupaten Maros jelas terlihat adanya mobilisasi pemilih saat kampanye.

Mobilisasi yang terjadi di desa Bontomatinggi memang sudah sering di setiap pemilihan utamanya pemilihan kepala desa yang berdampak ujaran kebencian setelah pemilihan yang tidak menerima dengan adanya mobillisasi yang dilakukan kepada dirinya. Mobilisasi ini dilakukan untuk kepentingan calon yang akan bertarung, mereka yang melakukan mobilisasi menganggap bahwa inilah salah satu jalan untuk meraut suara sehingga tidak memikirkan hal-hal yang negatif asalkan bisa mendapatkan suara sebanyak-banyaknya.

Mobilisasi politik di Desa Bontomatinggi tergolong sangat rawan terjadi konflik, karena mobilisasi yang dilakukan oleh calon atau tim sukses kepada masyarakat menggunakan cara-cara yang diluar dari aturan seperti adanya intimidasi, paksaan, bahkan ancaman. Mobilisasi politik itu sendiri dilakukan oleh orang-orang yang berpengaruh di desa tersebut mereka memanfaatkan kekuasaanya dengan cara memobilisasi masyarakat.

Adapun bentuk mobilisasi pemilihan kepala Desa tahun 2016 yang terjadi di Desa Bontomatinggi Kabupaten Maros dapat dilihat dari pembahasan sebagai berikut :

\section{Model Mobilisasi Langsung}

Bentuk mobilisasi langsung adalah merupakan kegiatan pengerahan dalam bentuk menggerakkan masyarakat agar melakukan tindakan politik sebagaimana yang dikehendaki. Mobilisasi langsung dapat dilakukan dengan turun langsung kemasyarakat seperti sosialisasi langsung, kampanye terbuka, menggerakkan atau mengerahkan simpatisan melakukan aksi-aksi politik namun mobilisasi tersebut diluar dari kata wajar untuk dilakukan. Berikut beberapa indikator mobilisasi langsung dibawah ini:

\section{a. Sosialisasi langsung}

Sosialisasi langsung merupakan tahap sosialisasi yang dilakukan secara face to face tanpa menggunakan media perantara komunikasi. Sosialisasi langsung biasanya dilakukan oleh seseorang yang akan melakukan kampanye politik dalam menyampaikan visi misi atau pesan-pesan politiknya kepada masyarakat secara langsung guna meyakinkan mereka dalam menentukan pilihannya sebelum hari $\mathrm{H}$, ini juga merupakan strategi para calon yang akan bertarung dalam pemilu atau pilkades agar masyarakat mengetahui apa yang menjadi tujuan dan target setelah terpilih.

Berdasarkan dari hasil wawancara informan penulis mengambil kesimpulan bahwa pada saat kampanye atau jauh-jauh hari sebelum pemilihan calon dan tim sukses tidak melakukan sosialisasi kepada tokoh-tokoh masyarakat bahkan masyarakat pada umumnya yang ada di Desa Bontomatinggi, sosialisasi itu hanya dilakukan kepada pihak-pihak tertentu saja seperti keluarga dan sebagian anak muda.

\section{b. Pengerahan/dorongan}


Pengerahan merupakan bentuk mobilisasi yang dilakukan dengan cara mengumpulkan pemilih , penjemputan pemilih bahkan menjanjikan sesuatu kepada pemilih agar mau ikut berpartisipasi dalam pemilihan, dimana pengerahan ini biasanya dilakukan oleh para pemangku kepentingan yang mempunyai pengaruh atau mempunyai alat transportasi seperti kendaraan roda 4, mereka memanfaatkan modal tersebut dengan cara melakukan proses penjemputan pemilih hingga ke tps. Pengerahan juga dilakukan dengan cara mempengaruhi para pemilih agar mau memilih calon yang diusung, biasanya dilakukan oleh orang-orang yang memang disegani di desa.

Pengerahan pemilih di desa Bontomatinggi terjadi karena beberapa faktor salah satunya sebagian masyarakat yang jauh dari tps dimanfaatkan oleh calon atau tim sukses yang memiliki figur berpengaruh dan memiliki alat transportasi, sedangkan dari pihak calon lainnya yang tidak memiliki hal tersebut merasa kecewa dengan apa yang dilakukan oleh pihak yang dimaksud.

Berdasarkan hasil wawancara, pengerahan atau dorongan yang di lakukan oleh tim sukses calon kepala Desa terpilih dan calon yang kalah memang terjadi dalam bentuk penjemputan, faktor kekeluargaan dan pemberian uang. Jika melihat hasil wawancara dari informan, penulis bisa simpulkan bahwa politik yang terjadi pada saat proses kampanye pemilihan kepala desa kurang mendidik, apa yang dilakukan oleh tim sukses sangat tidak pantas untuk dijadikan contoh dalam sebuah pemilihan, ini menandakan bahwa tim ke 2 calon antara Khaerul dan Abdullah sangat ngotot untuk memenangkan pilkades apalagi dalam proses kampanye tersebut ada penjemputan pemilih, money politik serta intimidasi kepada masyarakat dan keluarganya sendiri.

\section{c. Kampanye terbuka}

Kampanye adalah kegiatan peserta pemilu untuk meyakinkan para pemilih dengan menawarkan visi dan misi kepada masyarakat secara terbuka di depan umum yang dilakukan sebelum pemilihan dengan tujuan untuk mendapatkan dukungan dari pemilih, bisa dilakukan oleh perorangan atau sekelompok orang terorganisir untuk melakukan suatau proses pengambilan keputusan di dalam satu kelompok.

Dari hasil wawancara, apa yang dilakukan oleh calon kepala Desa terpilih sebagian sudah benar namun dikotori dengan adanya pemeberian uang yang dilakukan oleh tim suksesnya bahkan jumlah uang yang diberikan kepada masyarakat cukup banyak sehingga masyarakat dengan mudah tergoda untuk di mobilisasi sedangkan Ibu Muliaty hanya bermodalkan kekerabatan dan kedekatan kepada masyarakat. Kampanye yang dilakukan oleh calon atau tim sukses berbeda-beda seperti dengan cara memobilisasi dalam bentuk pemberian uang dan dijanjikan pekerjaan. Penulis menilai bahwa apa yang dilakukan oleh calon tidak mencerminkan seorang calon pemimpin yang baik, karena dari awal apa yang mereka lakukan sudah tidak benar dan juga setelah terpilihnya, apa yang dijanjiikan oleh kepala desa terpilih tidak terbukti.

\section{d. Intimidasi/ancaman}

Intimidasi merupakan perilaku agresif yang disengaja untuk membuat tekanan kepada orang lain baik secara fisik maupun psikologis atau suatu bentuk pengendalian sosial yang disertai dengan ancaman, paksaan dan menakut-nakuti seperti yang terjadi pada pemilihan kepala desa Bontomatinggi, adanya intimidasi yang dilakukan oleh salah satu tim sukses kepada keluarganya agar mau mengikuti calon yang dikehendakinya. Dari penjelasan di atas muncul lah konflik antara pihak-pihak yang melakukan mobilisasi dengan yang di mobilisasi seperti adanya ancaman dari tim sukses calon kepada keluarganya sendiri karena perbedaan pilihan.

Dari hasil wawancara dengan informan, terlihat bahwa ada tekanan dari pihak salah satu calon agar memilih calonnya dan dirinya tidak segan-segan mengancam masyarakat yang juga keluarganya dengan kata-kata yang kasar, apa yang dikatakan oleh tim sukses salah satu calon memang benar-benar ingin memenangkan Abdullah. Berdasarkan pengamatan, penulis menilai bahwa salah satu tim sukses calon sangat berambisi agar 
Vol.1 No.4. Januari 2019. pp.1-17. Copyright@2019 PUBLICUHO Faculty of Social and Political Sciences Halu Oleo University, Kendari, Southeast Sulawesi, Indonesia. ISSN: 2460-058X | e-ISSN: 2621-1351. Open Access at: http://ojs.uho.ac.id/index.php/PUBLICUHO

Jounal publiuho is licensed under a Creative Commons Attribution 4.0 International License, which permits unrestricted use, distribution, and reproduction in any medium, provided the original work is properly cited.

terpilih dan kelihatannya pihak yang melakukan mobilisasi tidak ingin jika Ibu Muliaty terpilih kembali dengan berbagai alasan salah satunya tidak ingin di pimpin oleh perempuan yang kedua ada rasa senggang dari beberapa orang jika ada keperluan dan yang ketiga bukan asli desa Bontomatinggi.

Berdasarkan hasil observasi penelitian, bentuk mobilisasi langsung yang terjadi yaitu, sosialisasi , pengerahan atau dorongan, kampanye terbuka dan mobilisasi dengan bentuk intimidasi dan ancaman sebagian besar masyarakat yang dimobilisasi ini diberikan uang serta adanya ancaman dari pihak tim sukses.

Kemudian faktor lain adalah kurangya pendidikan politik yang mereka dapatkan sebagian besar masyarakat di desa Bontomatinggi yang memang sebagian besar masyarakatnya tidak tamat SD dan para toko-toko masyarakat tidak paham apa itu mobilisasi politik dan bagaimana dampak dari mobilisasi itu ketika terus menerus dilakukan setiap pemilihan. Pokok persoalan di desa Bontomatinggi yaitu dari sektor pendidikan yang hanya beberapa orang saja yang bisa tamat sma dan hanya 2 sampai 3 orang yang sarjana ditambah adanya pembunuhan karakter dari orang-orang yang ingin memegang kekuasaan.

\section{Model Mobilisasi Tidak LangsungSgsgsg}

Bentuk mobilisasi tidak langsung merupakan bentuk mobilisasi secara kasat mata tidak langsung dilakukan antara pihak yang memobilisasi dan pihak yang dimobilisasi tetapi biasanya dilakukan dengan cara mempengaruhi cara pandang pemilih sehingga pemilih akan mengekspresikan pemahamannya dalam bentuk keputusan politik.

Mobilisasi tidak langsung biasanya menggunakan media untuk mempengaruhi pemilih tetapi yang terjadi di desa Bontomatinggi mobilisasi tidak langsung dilakukan dengan cara mempengaruhi cara pikir pemilih melalui kampanye tatap muka dan lewat telepon.

\section{a. Kampanye dialogis}

Kampanye dialogis adalah kampanye yang dilakukan secara langsung dengan para mesin-mesin politik guna persiapan masa kampanye, dimana parpol atau aktor politik mendekatkan calon pemimpin dengan rakyatnya, lewat kampanye dialogis komunikasi dengan rakyat akan tercipta dua arah. Calon pemimpin bisa menyerap apa yang menjadi aspirasi rakyatnya dan rakyat bisa mendapat ruang untuk bicara.

Kampanye dialogis mempunyai 4 manfaat jika dilakukan sesuai tupoksinya pertama, sejatinya kampanye kegiatan adu ide dan gagasan dan adu program. Kedua, dalam kampanye dialogis ada ruang bagi pemilih untuk berfikir secara kritis dan rasional, menelaah dan menguji program atau gagasan yang ditawarkan oleh calon atau tim suksesnya. Ketiga, kampanye dialogis memberikan pendidikan politik yang mencerahkan mendidik masyarakat dan program-program parpol dan calonpun bisa ditawarkan lebih transparansi dan yang keempat, masyarakat tidak sekedar berkumpul bersuka ria sebagai massa tapi lebih partisipatif dan menempatkan rakyat sebagai subyek dalam proses politik dan pembangunan.

Berdasarkan hasil penelitian dan wawancara dengan informan, menunjukkan bahwa pada masa-masa sebelum pemilihan atau masa kampanye, ada kampanye dialogis dari calon langsung bertatap muka dengan masyarakat utamanya pemuda.

\section{b. Mempengaruhi cara fikir/pandang}

Mempengaruhi cara fikir merupakan tindakan yang dilakukan seseorang untuk mempeangruhi perilaku dan sikap seseorang dalam menentukan pilihannya terhadap sesuatu berdasarkan sudut pandang tertentu sedangkan cara pandang merupakan pembentukan persepsi atau penilaian dalam sudut pandang terhadap suatu objek. 
Berdasarkan hasil wawancara dari Ketua panitia pilkades bahwa dorongan yang dilakukan oleh calon ada tetapi hanya mempengruhi cara fikir mereka dengan tujuan memilih calonnya, namun berbeda dengan apa yang penulis alami sebagai korban mobilisasi pada saat pemilihan pilkades Bontomatinggi melalui media massa (via sms) dari salah satu tim sukses kemudian dipengaruhi memilih calonnya dengan cara sedikit mengintimidasi atau ada unsur ancaman.

Berdasarkan dari wawancara dengan informan, penulis dapat menyimpulkan bahwa banyak yang menjadi korban mobilisasi pada saat pemilihan kepala desa Bontomatinggi melalui media, tetapi tidak secara keseluruhan, yang dimobilisasi dan yang memobilisasi hanya orang-orang tertentu saja dengan berbagai macam mobilisasi seperti mempengaruhi pemilih melalui media massa telepon genggam. kalau berupa seminarseminar dan media maenstrem atau media-media iklan lainnya tidak ada.

Dari berbagai bentuk mobilisasi tidal langsung diatas penulis menemukan bentuk lain yaitu :

\section{c. Kampanye Hitam}

Kampanye hitam adalah kampanye yang mengarah ke pembunuhan karakter dan cenderung fitnah yang isinya kebohongan dan tuduhan tanpa bukti. Kampanye hitam dilakukan untuk mengangkat citra baik dimata pemilih untuk meraih simpati. Tetapi kampanye hitam juga berpotensi memberikan citra buruk dimata setiap konstituen.

Cara-cara kampanye hitam yang biasa dilakukan yaitu :

Pertama, menyebarkan kejelekan atau keburukan tentang seorang politikus, dengan cara memunculkan cerita buruk di masa lalunya, menyebarkan cerita yang berhubungan dengan kasus hukum yang sedang berlangsung atau menyebarkan cerita bohong atau fitnah lainnya. Kedua, untuk menguatkan cerita tersebut biasanya si penyebar cerita akan menyertakan berupa bukti foto-foto tersebut bisa saja benar-benar terjadi tapi tidak terkait langsung dengan pemasalahan. Ketiga, apabila memunculkan saksi hidup yang bercerita perihal keburukan atau pekerjaan jahat si politikus baik dimasa lalu bmaupun yang masih belum terjadi.

Pemilihan kepala desa Bontomatinggi memang terjadi kampanye hitam yang dilakukan masing-masing calon sebagai strategi mereka untuk merubah pandangan pemilih. Kampanye hitam itu dilakukan jauh-jauh sebelum pemilihan dilakukan, kampanye hitam yang dilakukan tim sukes dengan menceritakan keburukan masa lalu calon tetapi ditujukkan kepada keluarga calon yang pernah ada kasus terhadap dirinya atau keluarganya dan terkadang tim sukses ini menceritakan kepada masyarakat bahwa jangan memilih calon yang dalam keluarganya ada yang kurang bagus sikapnya.

Berdasarkan dari hasil wawancara di atas penulis menemukan hal yang baru dalam strategi mobilisasi politik yang terjadi di desa Bontomatinggi yaitu saling membicarakan keburukan dari masing-masing calon yang kemudian dilakukan oleh tim sukses sebagai jurus atau taktik mempengaruhi pemilih.

Dari hasil wawancara, penulis menarik kesimpulan bahwa kampanye yang dilakukan tim sukses diluar dari aturan menurut Undang-undang berdasarkan Badan Pengawas Pemilu Nomor 6 Tahun 2014 Tentang Pedoman Pengawasan Pemilihan Umum pasal 14 yang berisi yaitu melakukan pencegahan kepada pelaksana, peserta dan petugas kampanye yang melakukan kegiatan seperti Mempersoalkan dasar Negara Pncasila, Membahayakan keutuhan NKRI, Menghina seseorang, agama, suku, ras, golongan, calon dan peseta pemilu, Menghasut dan mengadu domba perseorangan ataupun masyarakat, Mengganggu ketertiban umum, Mengancam untuk melakukan kekerasan atau menganjurkan kekerasan kepada seseorang, sekelompok anggota masyarakat dan peserta pemilu, Merusak dan menghilangkan alat peraga kampanye peserta pemilu, Menggunakan fasilitas pemerintah, tempat ibadah dan tempat pendidikan, Membawa atau menggunakan tanda 
Vol.1 No.4. Januari 2019. pp.1-17. Copyright@2019 PUBLICUHO Faculty of Social and Political Sciences Halu Oleo University, Kendari, Southeast Sulawesi, Indonesia. ISSN: 2460-058X | e-ISSN: 2621-1351. Open Access at: http://ojs.uho.ac.id/index.php/PUBLICUHO

Jounal publiuho is licensed under a Creative Commons Attribution 4.0 International License, which permits unrestricted use, distribution, and reproduction in any medium, provided the original work is properly cited.

gambar pesserta pemilu yang bersangkutan, Menjanjikan atau memberikan uang atau materi lainnya kepada peserta kampanye dan Memobilisasi warga negara indonesia yang belum memenuhi syarat sebagai pemilih.

Secara keseluruhan, hasil wawancara dengan informan, penulis menemukan 2 model mobilisasi politik dengan cara melakukan intimidasi/ancaman dan kampanye hitam kepada masyarakat. Hal ini menandakan bahwa mobilisasi politik dalam pemilihaan bisa dilakukan dengan berbagai cara untuk mencari dukungan tidak hanya dengan mempengaruhi seseorang untuk memilih namun ada juga pemberian sejumlah uang, sembako dan lain sebagainya.

\section{Dampak Mobilisasi Setelah Pemilihan Kepala Desa}

Dampak merupakan sesuatu yang diakibatkan dari apa yang telah dikerjakan atau dilaksanakan, apakah dampak tersebut negatif atau positif. Pemilhan kepala desa Bontomatinggi telah dilaksanakan pada tahun 2016 silang dimana pemilihan tersebut diwarnai dengan berbagai persoalan salah satunya yang berkaitan dengan kampanye yang dilakukan oleh calon atau tim sukses, dimana pihak dari masing-masing calon menggunakan berbagai strategi dalam mencari dukungan seperti dukungan dengan cara mobilisasi masyarkat.

Model mobilisasi politik yang terjadi di Desa Bontomatinggi memang diluar dari batas karena mobilisasi tersebut mengakibatkan kurangnya partisipasi sesuai hati nurani oleh masyarakat akan tetapi partisipasi itu dilakukan karena faktor mobilisasi yang dilakukan oleh pihak yang memobilisasi.

Dampak mobilisasi pemilihan kepala desa Bontomatinggi sebenarnya baru terjadi pada tahun 2016 dimana dampak yang saya lihat itu hanya dampak negatif, karena adanya rasa malu atau yang biasa disebut siri dari pihak-pihak yang melakukan mobilisasi dengan cara yang negatif.

Secara umu, berikut beberapa dampak yang terjadi setelah di laksanakan pemilihan Kepala Desa Bontomatinggi, berdasarkan dari hasil observasi yang dilakukan, penulis menemukan berbagai macam persoalan sebelum pemilihan dan beberapa dampak yang terjadi setelah pemilihan kepala desa sesuai hasil wawancara, penulis mengambil kesimpulan bahwa pemilihan kepala desa Bontomatinggi menuai pro dan kontra setelah pemilihan karena banyak faktor sehingga menimbulkan dampak negatif, salah satunya yang menjadi perhatian penulis adalah adanya pihak-pihak yang memutuskan pindah ke desa tetangga setelah pemilihan, hubungan keluarga tidak terjalin dengan baik, pendukung yang satu dengan yang lainnya tidak saling menegur dan hal-hal lainnya sedangkan dampak positifnya yaitu sebagian masyarakat senang karena yang terpilih putra daerah Bontomatinggi.

\section{KESIMPULANN}

Berdasarkan uraian dan pembahasan di atas maka penulis menarik simpulan penelitian bahwa Model mobilisasi politik yang terjadi di desa Bontomatinggi pada pemilihan kepala desa tahun 2016, sesuatu hal yang tidak dapat di contoh untuk para calon-calon pemimpin yang akan bertarung dalam sebuah pemilihan guna mendapatkan suara, karena dapat berakibat buruknya sebuah pesta demokrasi. Munculnya berbagai bentuk mobilisasi yang dilakukan oleh pihak calon disebabkan oleh beberapa hal :

1. Proses bentuk mobilisasi yang terjadi di Desa Bontomatinggi diakibatkan kerasnya persaingan sehingga memaksa calon untuk melakukan berbagai dorongan dalam mencari dukungan dan posisi pemilih yang memang sudah berada pada berbagai tekanan mobilisasi sehingga pemilih tersebut dilema yang pada akhirnya berefek buruk setelah pemilihan.

2. Kurangnya pendidikan dan pemahaman politik sehingga masyarakat desa Bontomatinggi mudah dimobilisasi dengan bentuk apapun seperti pemberian uang, pengerahan, intimidasi, kampanye hitam dan mempengeruhi cara fikir/pandang pemilih dan pihak yang melakukan mobilisasi tidak memikirkan efek buruknya setelah pemilihan yang menimbulkan ujaran kebencian. 
3. Masyarakat yang dimobilisasi takut akan ada kekerasan dan kebencian dari tim sukses ketika tidak mengikuti apa yang dikehendakinya, apa lagi yang melakukan mobilisasi itu dari keluarga sendiri, karena semakin tinggi tingkat pengenalan antara pihak yang dimobilisasi dan pihak yang memobilisasi maka semakin kuat juga tekanan mobilisasi.

\section{SARAN}

1. Bagi pemerintah khusunya pemerintah yang berkaitan dengan persoalan pemilihan harus lebih tegas dalam mengawasi calon-calon atau tim sukses yang akan melakukan kampanye agar tidak ada lagi kampanye-kampanye seperti yang penulis jelaskan dalam skripsi ini. dan harus ada pengawasan setiap kampanye yang dilakukan oleh pihak yang terakait, bekerja sama dengan kepolisian agar mengawasi halhal yang tidak di inginkan pada saat kampanye.

2. Untuk calon kepala desa dan tim sukses agar lebih mempertimbangkan lagi dampak-dampak yang akan terjadi jika akan melakukan kampanye dengan cara mobilisasi secara tidak sehat kepada pemilih, agar dalam sebuah pesta demokrasi dapat berjalan dengan baik.

3. Khususnya masyarakat yang menjadi aktor untuk dimobilisasi, saran penulis, jadilah pemilih cerdas dalam menentukan pilihannya, cari taulah informasi mengenai calon-calon yang akan bertarung, ketahuilah pengalaman atau track record yang mereka miliki apakah pantas untuk jadi pemimpin atau tidak dan yang terakhir hindari mobilisasi yang dilakukan oleh pihak-pihak yang ingin calonnya terpilih dengan bentuk mobilisasi apapun, baik itu pemberian uang, dijanjikan sesuatu dan intimidasi dengan cara menghindari hal-hal negatif yang dilakukan oleh phak-pihak tertentu dan jika ada kecurangan dalam proses kampanye baiknya dilaporkan kepada pihak terkait.

\section{DAFTAR PUSTAKA}

Almond, Gabriel A. And G Bingham, Jr, 1976. Comparative Politics: A Develomental Approach. Ne Delhi, Oxford and IBH Publishing $\mathrm{C}$.

Burhan Bungin.2003. Penelitian Kualitatif.Jakarta:PT Raja Grafindo Persada.

Charles Tilly, 2004， Social Movements 1768-2004 (London : Paradigma Publisher.

Giddens, Anthony. 1999. The Third Way: Jalan Ketiga Pembaruan Demokrasi Sosial. Jakarta: Gramedia Pustaka Utama.

Hanif Nurcholis,2011. Pertumnthan dan Penyelenggaraan Pemerintahan Desa, 69.Jakarta.

Huntington P. Samuel, 1994. Partisipasi Politik di Negara Berkembang. Jakarta: Rineka Cipta.

Jeffrey I. 1999. Local Goverment, Fiscal Autonomy and Fiscal Stress: The case of California. Working Papers, LincoIn Institute of Land Policy.

Karp,Jeffrey A.; Banducci, Susan A.;Bowle, Shaun, 2007. Getting Out the vote. Party Mobilization in a comparative Perspective,Cambridge: Cambridge University Pess.

Leo Agustina. 2009, Pilkada dan Dinamika Politik Lokal. Yoyakarta:Pustaka Pelajar. 
Vol.1 No.4. Januari 2019. pp.1-17. Copyright@2019 PUBLICUHO Faculty of Social and Political Sciences Halu Oleo University, Kendari, Southeast Sulawesi, Indonesia. ISSN: 2460-058X | e-ISSN: 2621-1351. Open Access at: http://ojs.uho.ac.id/index.php/PUBLICUHO

(9) Jounal publiuho is licensed under a Creative Commons Attribution 4.0 International License, which permits BY unrestricted use, distribution, and reproduction in any medium, provided the original work is properly cited.

McAdam, Jhon D McCarthy, 1996. Comparative Perspectives on Social Movements: Political Opportunities, Mobilizing Structures, and Cultural Framming. Cambridge/New York: Cambridge University Press.

Myron, Weiner 1986, Modernisation The Dinamic of Growth. New York: Basic Books.

Nedelman, Birgitta. 1987, Individuals and Parties-Chnges in Processes of Political Mobilization, European Sociological Revie, Oxford University Press.

Singh, Rajendra. 2001. Social Movements, Old and New: a Post-Modemist Critique. New Delhi/Thousand Oaks/London: Sage Publications.

Stefano, B. 2007. The Political Mobilization of the European Left, 1860-1980 : The class Cleavage, Digital Printed Version. New York : Cambridge University Press.

Sugiyono. 2007. Metode Penelitian Kuantitatif Kualitatif dan R\&D. Bandung: Alfabeta.

Tarrow, Sidney. 1998. Social Movements and Contentious Politics. Cmabridge: University Press.

Verba, Scholzman, and Brady , 1995 Civic Voluntarism Model of Participation.

Widjaja, HAW, 2008. Otonomi Desa : Merupakan Otonomi yang Asli, Bulat dan Utuh, Rajawali Pers, Jakarta.

\section{Sumber Undang-Undang :}

Pemerintahan Republik Indonesia 2014, Undang-Undang Nomor 23/ 2014 Tentang Pemerintahan Daerah. Bening, Yogyakarta.

Pemerintahan Republik Indonesia 2014, Undang-Undang Nomor 35/2014 Tentang Desa, Bening, Yogyakarta.

Pemerintah Republik Indonesia, 2014 Undang-undang Nomor 6 Tentang Pedoman Pengawasan Pemilihan Umum Pasal 14, Jakarta.

Peraturan Pemerintah Republik Indonesia Nomor 72 Tahun 2005 tentang Desa

Sumber lain :

Kantor Desa Bontomatinggi

Ketua Panitia Kelompok Pelaksana Pemungutan Suara (KPPS) 